\section{A study to explore internal auditors' compliance with Quality Assurance Standards: A case of state owned corporations in Kenya}

Okibo, Bichanga Walter $\bowtie$

Jomo Kenyatta University of Agriculture and Technology, Nairobi, Kenya (walter.okibo@yahoo.com)

Kamau, Charles Guandaru

Jomo Kenyatta University of Agriculture and Technology, Nairobi, Kenya (guandaruman@yahoo.co.uk)



Received: 10 September 2011

Revised: 15 December 2011

Accepted: 7 January 2012

Available Online: 10 February 2012

DOI: $10.5861 / \mathrm{ijrsm} .2012 . \mathrm{v} 1 \mathrm{i} 1.45$

\title{
Abstract
}

The Internal Audit Department in any organization (including State Owned Corporations) has a role of assisting the management in achieving their objectives and adding value to organizational operations by evaluating and improving the effective of risk management, internal controls and governance processes. To achieve this, the Internal Audit Department is required by the Institute of Internal Auditors (IIA) to carry out a continuous internal quality assessment and an external assessment at least once in five years. The literature suggests that internal auditors in Africa including Kenya do not comply with the quality assurance standards as set by the IIA. This research collected data from 24 Internal Audit Units from State Owned Corporations regarding their compliance with quality assurance standards. The research carried out a hypothesis testing using the data collected to find out whether the audit departments in state owned corporations comply with quality assurance standards. The study found out that there is generally low compliance with quality assurance standards among most internal audit units in state owned corporations in Kenya. The research identified some of the reasons that led to low compliance to include; lack of awareness of standards; non-membership with IIA; non adoption of IPPF; age and experience of the internal audit department and understanding of the quality assurance standards.

Keywords: internal auditors; compliance; quality assurance standards; effective of risk management; internal controls; governance processes

Acronyms: Chief Audit Executive (CAE), Chief Executive Officer (CEO), Chief Finance Officer (CFO), Generally Accepted Auditing Standards (GAAS), Internal Audit Department (IAD), Institute of Internal Auditors (IIA), International Professional Practice Framework (IPPF), Kenyatta International Conference Centre (KICC), Malaysian Institute of Accountants (MIA), Quality Assessment (QA), United States of America (USA) 


\section{A study to explore internal auditors' compliance with Quality Assurance Standards: A case of state owned corporations in Kenya}

\section{Introduction}

The quality assurance standards for Internal Auditors are set by the Institute of Internal Auditors (IIA). The Institute of Internal Auditors is a worldwide professional organization, whose role is to provide leadership to internal auditors' worldwide through training and certifications, setting standards and developing global relationships, enhance professional requirements, promoting organizational (internal audit) quality, and to define audit principles (The Institute of Internal Auditors, 2010; Gerry Cox, 2007). IIA sets standards that should guide the internal auditors in performing their duties. Through setting of standards and providing leadership the IIA seeks to standardize the operations of all the internal audit units throughout the world.

The IIA Kenyan Chapter was registered in December 2002 under the Registrar of Societies Act, and launched officially in April 2003. Owour (2010), indicated that role of IIA Kenya chapter is to uphold the Standards for the Professional Practice of Internal Auditing and constantly improve the internal auditing professionalism in the country. It brings the internal auditors together to share experiences through such forums as seminars, trainings, dinners, and general meetings.

One of the main roles of IIA is setting standards. The IIA professional Standards committee developed the Internal Auditing Standards based on its professional expertise as well as comments received from IIA members and other interested parties (Moeller, 2009). The Internal Auditing Standards are contained in a book known as International Professional Practices Framework (IPPF). The IPPF is divided into five sections which include; definition of internal auditing, code of ethics for internal auditors, attribute standards, performance standards, and practice advisories (Janet, 2002). IIA call for mandatory compliance with the standards. Quality assurance standards are part of attribute standards in the PPF. The IIA recognizes the fact that full compliance with standards may not be possible despite the fact that compliance with standards is mandatory

Quality Assurance Standards are contained in standards number 1300 to 1340 in the IPPF under the title Quality assurance and improvement program. Standards number 1300 to 1340 requires the internal audit departments to have programs that will continuously monitor the overall effectiveness and quality of internal audit work. The quality assurance exercise should also ensure that the internal audit departments comply with the IPPF. The quality assurance standards also require the internal audit department to carry out a continuous internal quality assessment and an external quality assessment at least once in every five years (The Institute of Internal Auditors, 2004).

Mohammad (2009) indicates that since IIA has affiliates in 165 countries across the world, it is possible that there are differences in practice such as extent of use of Internal Auditing Standards and compliance with sections of standards such as Quality Assurance Standards. Quality assurance standards guarantee that important aspects in performance of internal audit have been carried out in accordance with the laid down standard. Internal auditors who consistently carry out the quality assurance assessments are guaranteed of high quality audit work if they follow up on the results of such assessments with an aim of improving the quality of their work.

According to The Institute of Internal Auditors (2004), compliance refers to conformity and adherence to policies, plans, procedures, laws, regulations, contracts, or other requirements. It is the responsibility of the Chief Audit Executive (CAE) to ensure that the internal auditing standards are complied with by the audit departments they head.

As per Jonathan and Simon (2005), compliance is central to the operation and reputation of the financial 
services sector and is now completely embedded in the way financial services are carried out. Therefore, compliance with the quality assurance standards by the internal audit departments is important as they perform their work. Quality assurance standards help the internal audit units check the quality and to ensure continuous quality improvement on the identified weaknesses in their work.

The quality and credibility of audit work have implications on the organizational operations and performance. This is mainly because; internal audit units have a role to assist the management of the organization to add value to its operations and governance processes so as to support the organization in achieving its objectives. The quality of audit work is to a great extent dependent on the compliance with the relevant standards (Jun et al., 2009). The quality of internal audit work may therefore be improved by compliance with IIA quality assurance standards.

A study conducted in Arkansas was focused on public sector audits; an important contribution of this study is the use of an observable quality measure as the dependent variable on audits performed in the private sector. The studies suggest that audit fees, the complexity of the engagement and membership in the state Certified Public Accountants' society are positively related to compliance with Generally Accepted Auditing Standards (Barry, 1996). Membership with professional bodies such as IIA will positively influence compliance with internal auditing standards by the internal audit units in the world.

Githua (2009) stated that state owned corporations in Kenya face quite a number of governance challenges including limited skilled manpower, poor strategic planning, insufficient research and obsolete technology, political interference among others. The internal auditors have a role in assisting these organizations to address some of the challenges. The role of internal auditors is to add value to organizations operations through assurance and consultancy services to the management (Dessalegn et al., 2009). The Internal Audit Department should therefore comply with quality assurance standards so as to improve the quality of its work. This study is sought to find out if there was compliance, and the extent of compliance with the quality assurance standards by internal auditors in the state owned corporations in Kenya.

\subsection{Statement of Problem}

The Internal Audit department has a role of assisting the management in achieving their objectives by reviewing the internal controls and carrying out risk assessments. The internal auditors help the management to identify areas where there are no controls or controls are weak thereby increasing risks such as loss of funds, frauds, misappropriation of assets, errors in accounting records and corruption. It is therefore important that the internal auditors work be of reasonably high quality.

IIA have set Quality Assurance Standards in an attempt to improve the quality of internal auditors' work. Compliance with the Quality Assurance Standards set by IIA is mandatory yet the internal auditors in Kenya in general seem not to be complying with the standards. Non-compliance with quality assurance standards implies that the quality of the internal audit work is not being checked by the Chief Audit Executives, or external assessors.

One of the foundations of the Kenyan Vision 2030 is continuity in governance reforms through intensifying the anticorruption program (Government of Kenya, 2007). Internal audit can be used as a tool to improve governance and in effect assist other government agencies in the fight against corruption. Lack of internal auditor's commitment to quality assurance and quality improvement may impact negatively on the performance of state owned corporations.

\subsection{Objective of the Study}

This study sought to find out whether internal auditors in State Owned Corporations in Kenya comply with Quality Assurance Standards. 


\subsection{Hypothesis}

Internal Auditors in State Owned Corporations do not comply with the Quality Assurance Standards.

\subsection{Significance of the Study}

According to Kihara, (2009), state owned corporations form a substantial portion of the Kenyan economy and they face quite a number of challenges ranging from poor strategic planning, limited skilled manpower, obsolete technology, insufficient research and political interference. Internal auditors also perform an important task in advising the management of an organization on how to improve their operations. The quality of internal auditors work therefore is of paramount importance. Compliance with internal auditing standards which includes quality assurance is meant to safeguard and improve the quality of internal auditors work.

Quality auditing of the State Owned Corporations will assist them to increase their profitability therefore implying high revenues to the government. High government revenue translates into increased economic development for the country. Increased economic development helps in improving production and wealth generation for the Kenyans. This demonstrates that the benefits of quality internal auditing of State Owned Corporations spread even to the community.

\section{Conceptual Framework}

In this research, compliance with quality assurance standards was the dependent variable. Several factors may lead to lack of compliance with quality assurance standards by internal auditors in the state owned corporations in Kenya. These factors become the independent variables in this research. They include: Awareness of standards - some auditors may fail to comply with quality assurance standards due to lack of awareness of existence of such standards. The higher the awareness of standards, the higher the likelihood of compliance by the internal auditors; Membership with IIA - the internal auditors who are not members of IIA are less likely to comply with the quality assurance standards. IIA requires that its members should comply with the internal auditing standards; Adoption of internal auditing standards - The internal audit units in state owned corporations may not have adopted the internal auditing standards developed by IIA. Quality assurance standards are part of internal auditing standards. The length of time since adoption of the internal auditing standards may also influence the level of compliance to the quality assurance standards; Age of the Internal Audit Department the internal audit departments which were established earlier are more likely to comply with the quality assurance standards. On the other hand the younger internal audit departments are less likely to comply with the internal auditing standards. The research attributed the age of internal audit department to its experience.

Independent Variables

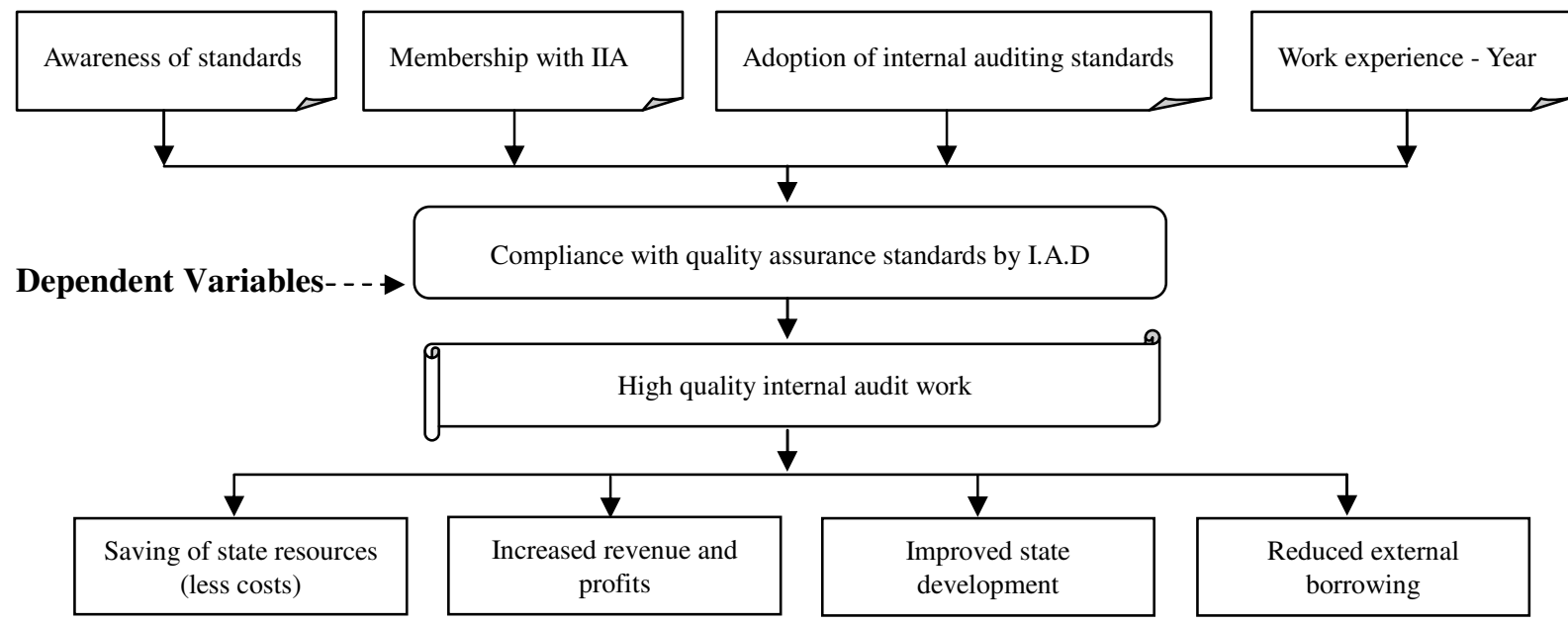

Figure 1. Conceptual framework 
Internal auditors' compliance with Quality Assurance Standards: A case of state owned corporation

The figure above shows the relationship between the various variables. Awareness of internal auditing standards, internal auditors' membership with IIA, adoption of internal auditing standards and the age of the internal audit department directly affect the compliance with quality assurance standards by the internal auditors. Compliance with quality assurance standards by the internal auditors helps them to continuously improve the quality of their work. High quality audit work means that the Internal Audit Department is working effectively. Effective internal auditors assists the management of state owned corporations to achieve their objectives by saving the resources hence reducing the costs, increased revenues and profits for the state owned corporations. This increases the revenue for the government which leads to increased economic development and reduced external borrowing.

\section{Literature Review}

This part sighted literature from the various books, journals, magazines, news papers, manuals and websites that relates to compliance of standards by internal auditors. It was divided into different sections: internal audit, Internal Audit in Kenya, Institute of Internal Auditors, quality of internal audit work, International Professional Practices Framework, quality assurance standards, Compliance with quality assurance standards and finally, the knowledge gap was identified.

\subsection{Knowledge Gap}

The review of literature suggests that there are researches that had been carried out mostly from USA and Europe. Kenya had only $0.1 \%$ representation in the sample of the IIA global survey that was carried out and touched on the issues of compliance with quality assurance standards. The little that has been done on Africa seems to suggest that though the internal auditors ware aware of the standards, most of the standards ware not complied with. However there was no research that had been carried out to describe status of auditor's compliance with quality assurance standards.

An informal discussion with the administrator of IIA Kenya reveals that, the actual situation in Kenya concerning compliance with internal auditing standards is yet to be established. This confirmed that there was no much that had been done to determine whether the internal auditors in Kenya and in particular those in the state owned corporations had complied with the quality assurance standards. This study contributed towards filling the knowledge gap by exploring the status of compliance with the quality assurance standards among the internal audit units in state owned corporations in Kenya.

\section{Research Design and Methodology}

This research employed a descriptive research design. Descriptive research is concerned with measuring a variable or set of variables and describing them as they exist naturally. It is not concerned with the relationships between the variables but with the description of the variables. The measurement and description of the variables may be carried out qualitatively or quantitatively (Gravetter, 2009). The research sought to find out whether the internal audit units in the state owned corporations in Kenya comply with quality assurance standards as required by the international auditing standards on quality assurance and to establish the reasons for non compliance with the standards. The measurement of compliance was carried out by use of Likert scales. The data collected using scales was coded and subjected to both descriptive and inferential statistics for analysis.

This study was carried out in Kenya's capital city - Nairobi where most of the state owned corporations have their head quarters. The study employed purposive sampling technique in determining State Owned Corporations as the target population. The research used judgment to settle on state owned corporations in Kenya as the target population. The research picked state corporations for this study because it is hard to know the number of companies in the private sector that have internal audit functions. The study targeted an estimated population of 85 State Owned Corporations in Kenya that had an Internal Audit Department. There were a total of 120 state owned corporations in Kenya that had an internal audit department. 85 corporations were based in Nairobi the 
capital of Kenya while 35 were outside Nairobi.

This study used systematic random sampling to select its sample. Systematic sampling is where every $\mathrm{k}^{\text {th }}$ item is selected into the sample. The first element is selected randomly so as to determine the starting point from which the every $\mathrm{k}^{\text {th }}$ item is selected. Every population element had to be assigned some unique numbers for easier identification (Ken Black, 2010). The research targeted a sample size of 30 state owned corporations based on the principle of central limit theorem. The research targeted to interview the head of internal audit departments from 30 state owned corporations which were selected randomly from corporations based in Nairobi. In this study each element was assigned a unique numeric code in ascending order starting from 1 to 85 and was subjected to systematic sampling.

The research randomly selected the first element to be included in the sample. The targeted state owned corporations based in Nairobi were 85 and the target sample was expected to be 30, therefore the research chose every $3^{\text {rd }}$ item to include it in the sample starting from the first item selected randomly. From the Internal Audit department the head of the internal audit or any other person appointed by him/her to be the respondent were interviewed. This research relied on the secondary data during the literature review. In order to meet the objectives of this research, primary sources of data were used to a greater extent. In this case the research interviewed the head of internal audit units or representative auditors from selected state owned corporations.

This study used interview as the method of data collection. Observation method was also used to compliment the interviews. The data collection tools that the research employed were a questionnaire for interviews and a checklist for observation. The questions in the questionnaire were both structured and unstructured i.e. some questions were closed ended, others were closed ended with a room for comments and a few questions were open ended. This allowed the research to accommodate the opinions of the respondents as well as increase accuracy of the data collection. Closed ended questions made data analysis easier while the open ended questions corroborated the evidence obtained from the closed ended questions. The research interviewed the target respondents as guided by the questionnaire.

Data in this study was analyzed both quantitatively using the SPSS program and Excel worksheets and qualitatively using narratives. The closed ended questions in the questionnaire were structured and coded so as to make the data analysis easier. The qualitative data collected was combined in groups after data collection for the purposes of easier analysis. The data collected was edited to eliminate the obvious data collection errors. The data was presented in form of descriptive narratives, frequency tables, Bar graphs and pie charts to explain the results of the observations made.

\section{Data Presentation and Analysis}

The research targeted a sample of 30 state owned corporations in Nairobi - Kenya, out of a population of 85 . 24 State Owned Corporations in Nairobi contributed to the research by filling in the questionnaires. This represents $80 \%$ of the originally targeted sample and $28.24 \%$ of the population. Therefore sample size for this study for the purpose of analysis is 24 state owned corporations.

\subsection{Compliance with Quality Assurance Standards}

Three out of 24 corporations which represent $12.5 \%$ of the respondents complied with the quality assurance standards to a greater extent, while $58.3 \%$ somewhat complied with the said standards and the remaining $29.2 \%$ had very little compliance. This result indicated that all the internal audit units in state owned corporations interviewed reported that they at least complied with the quality assurance standards. The only difference is the degree of compliance with the said standards. This implies that majority of auditors in state owned corporations carry out some form of quality check on their work. 


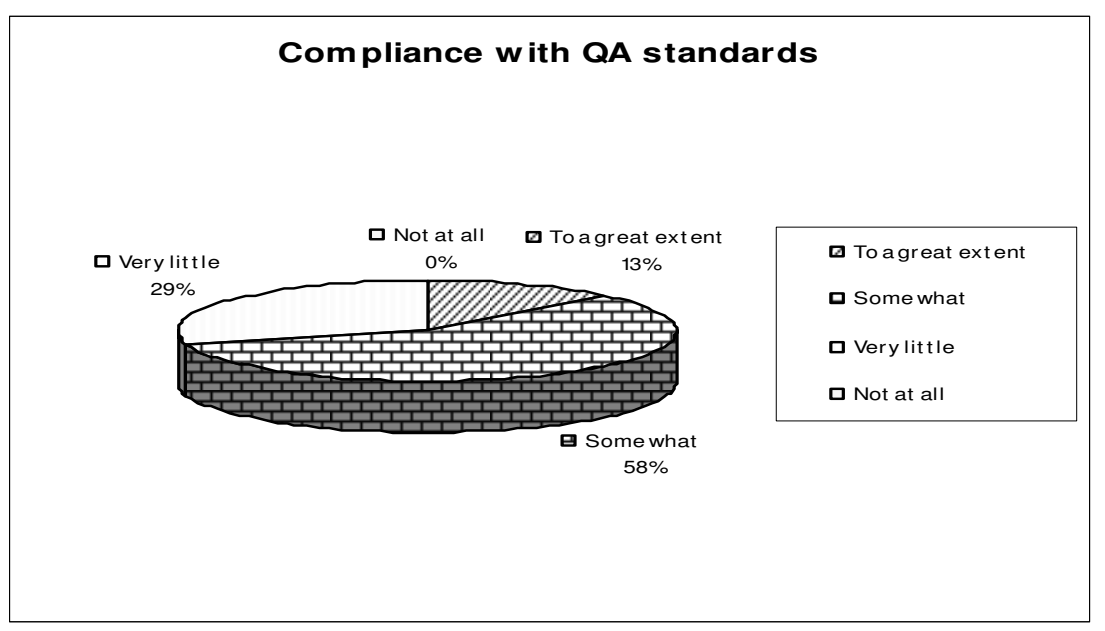

Figure 2. Compliance with quality assurance standards

5.2 Internal Quality Assessment

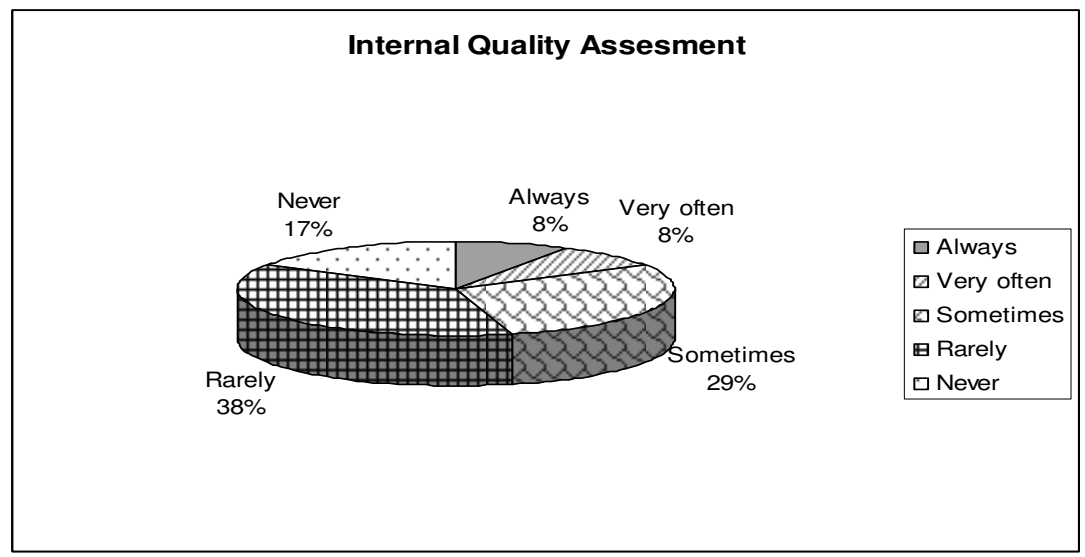

Figure 3. Internal quality assessment

Compliance with quality assurance standards means carrying out both internal and external quality assessments. From the above findings on internal quality assessment, the lowest level had $16.7 \%$ of the respondents reporting that they had never carried out internal quality assessment. Technically speaking, if an audit department doesn't carry out internal quality assessments, most likely they are not in compliance with quality assurance standards.

\subsection{External Quality Assessment}

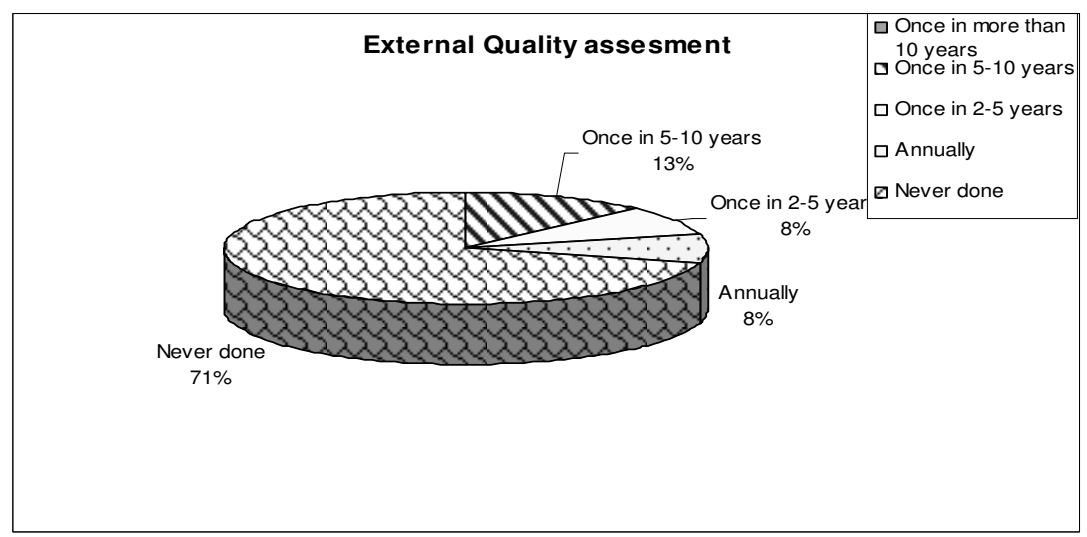

Figure 4. External quality assessment 
The recommendation by the internal auditing standards is that external quality assessment should be carried out at least once in every five years. Substantial majority of the respondents reported that they had never carried out external quality assessment. This could be due to the fact that some of internal audit units are not more than 10 years old. The standards required the external quality assessment to be carried out at least once in every five years.

\subsection{Compliance versus Internal Quality Assessment and External Quality Assessment (Correlation Analysis)}

The data on compliance with the Quality Assurance Standards, performance of internal quality assessment, and performance of external quality assessment was analyzed for correlation using the SPSS program and the results were as indicated in the table below.

\section{Table 1}

Compliance versus Internal Quality Assessment and External Quality Assessment

\begin{tabular}{llccc}
\hline & Items & Compliance & Internal QA & External QA \\
\hline Compliance & Pearson Correlation & 1 & $.608^{* * *}$ & .353 \\
& Sig. (2-tailed) & & .002 & .091 \\
& $\mathrm{~N}$ & 24 & 24 & 24 \\
Internal QA & Pearson Correlation & $.608^{* *}$ & 1 & $.576^{* *}$ \\
& Sig. (2-tailed) & .002 & & .003 \\
& N & 24 & 24 & 24 \\
External QA & Pearson Correlation & .353 & $.576^{* *}$ & 1 \\
& Sig. (2-tailed) & .091 & .003 & 24 \\
& $\mathrm{~N}$ & 24 & 24 & 24 \\
\hline
\end{tabular}

Note. ${ }^{* *}$ Correlation is significant at the 0.01 level (2-tailed)

Correlation analysis is helpful in revealing whether there is a positive or negative relationship between the independent and dependent variables. According to Rasli (2006), "If the absolute r-value is above 0.196, then there is a mild correlation. A somewhat correlation can be concluded if the absolute r-value is above 0.5. If the absolute r-value is exceeds 0.7 , the correlation is strong." The results of the table were interpreted as follows. There was a somewhat positive relationship between compliance with the Quality Assurance Standards and performance of internal quality assessment since the Pearson coefficient of correlation was 0.608; There was a mild positive relationship between compliance with the Quality Assurance Standards and performance of external quality assessment since the Pearson coefficient of correlation was 0.353; There was a somewhat positive relationship between performance of internal quality assessment and performance of external quality assessment since the Pearson coefficient of correlation was 0.576 . The positive correlations among compliance, internal quality assessment, and external quality assessment confirm some degree of consistency in the responses. Since most of the respondents were less than ten years in operation, the results of external quality assessment may be considered extraneous. The most reliable results are the results of internal quality assurance since they showed a higher consistency with both compliance and external quality assessment.

\subsection{Understanding of Quality Assurance Standards}

The respondents responded to a question on how well they understood the quality assurance standards as 
provided for in the IPPF.

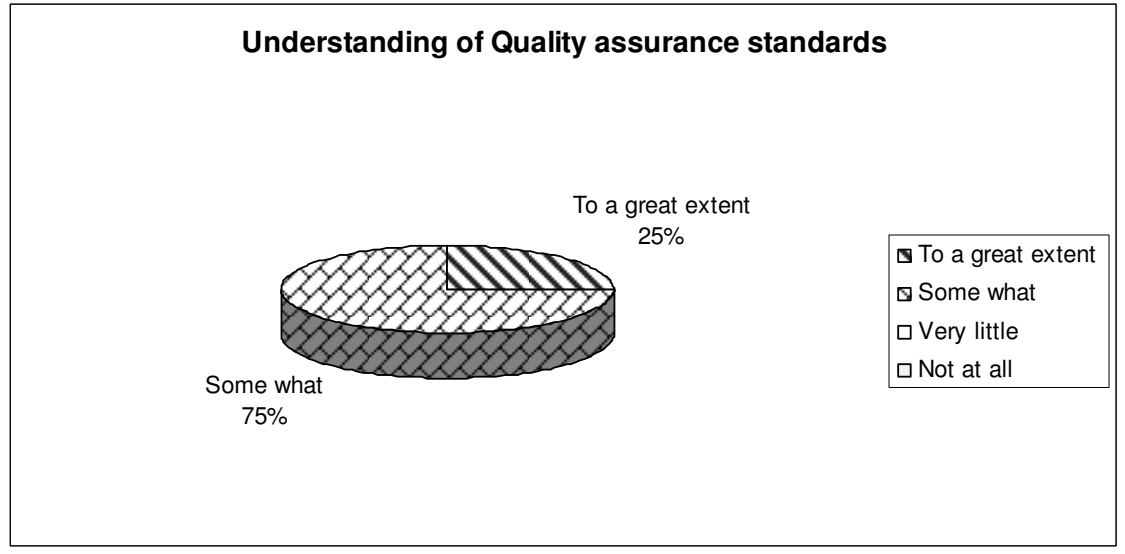

Figure 5. Understanding of quality assurance standards

This implied that all the internal audit units in State Owned Corporations possessed some level of understanding of quality assurance standards. This therefore meant that any lack of compliance with the standards is not as a result of ignorance.

\subsection{Compliance versus Understanding of Quality Assurance Standards}

The research compared the extent to which the respondents complied with the quality assurance standards with the extent to which they understood the quality assurance standards. The figure indicates that the respondents had relatively higher understanding of the Quality Assurance standards and relatively less degree of compliance with the standards. There was a higher degree of understanding than the degree of compliance with the quality assurance standards.

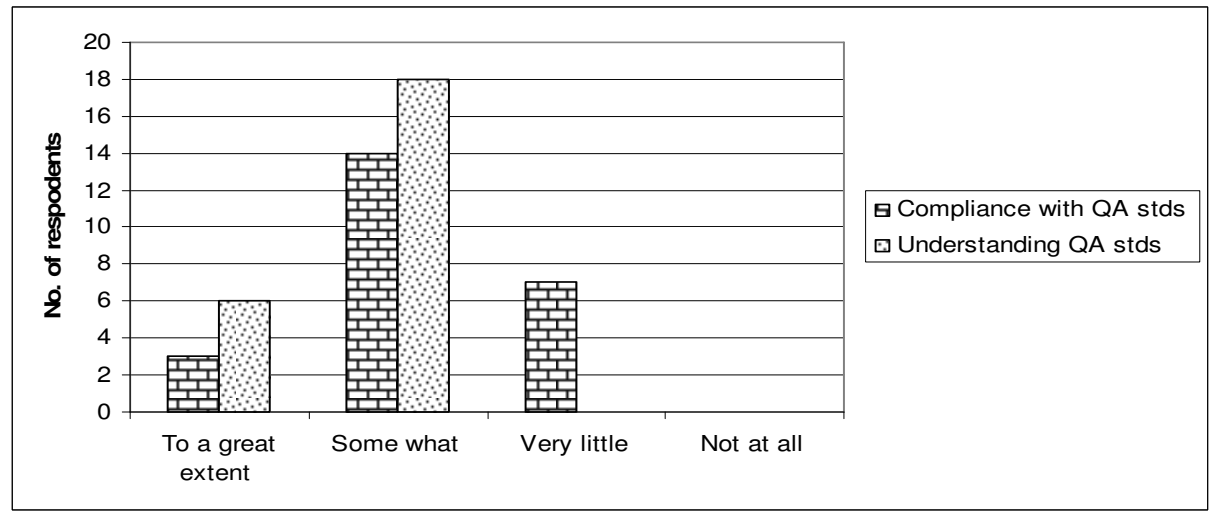

Figure 6. Compliance versus Understanding of Quality Assurance Standards

Correlation analysis indicated that there was a somewhat positive relationship between compliance with the Quality Assurance Standards and understanding of the standards since the Pearson coefficient of correlation was 0.617. This means that the level of compliance is highly dependent on the level of understanding of standards.

\subsection{Adoption of IPPF}

The survey also had a question on whether the audit departments in the state owned corporations have adopted the IPPF. This data implies that only $41.7 \%$ of the internal audit units interviewed was under mandatory obligation to comply with the quality assurance standards due to the fact that they had already adopted the IPPF. The rest $58.3 \%$ were only required to comply with the standards just as a best practice. 


\section{Table 2}

Compliance versus Understanding of Quality Assurance Standards

\begin{tabular}{llcc}
\hline & Items & Compliance & Understanding \\
\hline Compliance & Pearson Correlation & 1 & $.617^{* *}$ \\
& Sig. (2-tailed) & & .001 \\
\multirow{4}{*}{ Understanding } & $\mathrm{N}$ & 24 & 24 \\
& Pearson Correlation & $.617^{* *}$ & 1 \\
& Sig. (2-tailed) & .001 & 24 \\
\hline
\end{tabular}

Note. $* *$ Correlation is significant at the 0.01 level (2-tailed)



Figure 7. Adoption of IPPF

Table 3

Compliance versus Adoption of IPPF

\begin{tabular}{llcc}
\hline & Items & Compliance & Adoption \\
\hline Compliance & Pearson Correlation & 1 & $.632^{* *}$ \\
& Sig. (2-tailed) & & .001 \\
& $\mathrm{~N}$ & 24 & 24 \\
Adoption & Pearson Correlation & $.632^{* *}$ & 1 \\
& Sig. (2-tailed) & .001 & \\
& $\mathrm{~N}$ & 24 & 24 \\
\hline
\end{tabular}

Note. $* *$ Correlation is significant at the 0.01 level (2-tailed)

Correlation analysis results indicated that there was a somewhat positive relationship between compliance with the Quality Assurance Standards and adoption of the IPPF since the Pearson coefficient of correlation was 0.632. The correlation between adoption of IPPF and compliance level is significant. This means that adopting the IPF have a positive impact on compliance with quality assurance standards. More internal audit departments should be encouraged to adopt the IPPF and this would result to more audit units complying with quality 
Internal auditors' compliance with Quality Assurance Standards: A case of state owned corporation assurance standards.

\subsection{Age of the Internal Audit Department}

The respondents also provided the research with the details of the age of their internal units which was as provided in the following table.

\section{Table 4}

Age of the Internal Audit Department

\begin{tabular}{lcc}
\hline \multicolumn{1}{c}{ Age of IAD (in years) } & No. of respondents & Percentage respondents \\
\hline 1 & 0 & $0 \%$ \\
$2-5$ & 3 & $12.5 \%$ \\
$6-10$ & 13 & $54.2 \%$ \\
$11-20$ & 6 & $25 \%$ \\
more than 20 & 2 & $8.3 \%$ \\
TOTAL & 24 & 100 \\
\hline
\end{tabular}

The age of the internal audit department was measured by number of years the department was in existence. A total of $33.3 \%$ of respondents existed for more than 10 years while 66.7 of respondents were in existence for 10 years or less. This implies that two thirds of the respondents were relatively less experienced as compared with the rest. The research assumed that age of internal audit department would represent the level of experience for the purposes of this study.

Table 5

Compliance versus age of internal audit department

\begin{tabular}{llcc}
\hline & Items & Compliance & Age of IAD \\
\hline Compliance & Pearson Correlation & 1 & .237 \\
& Sig. (2-tailed) & & .266 \\
& $\mathrm{~N}$ & 24 & 24 \\
Age of IAD & Pearson Correlation & .237 & 1 \\
& Sig. (2-tailed) & .266 & 24 \\
\hline
\end{tabular}

There was a mild positive relationship between compliance with the Quality Assurance Standards and age of internal audit department since the Pearson coefficient of correlation was 0.237 . This implied that the level of compliance with quality assurance standards may not be related to age or experience of the quality assurance standards.

\subsection{Awareness of Standards}

All the 24 respondents reported that they were aware of the IPPF which contains the internal auditing standards. Therefore there was $100 \%$ awareness of the standards among the respondents who participated in this research. This also implied that all the respondents were somehow familiar with what the research was interested in. There was no relationship between compliance with the Quality Assurance Standards and awareness of standards since the Pearson coefficient of correlation was 0.000. This led to the conclusion that awareness of standards did not affect compliance. All the respondents were aware of the standards however the compliance level was not the same. 
Okibo, B. W. \& Kamau, C. G.

Table 6

Compliance versus awareness of standards

\begin{tabular}{llcc}
\hline & Items & Compliance & Awareness \\
\hline Compliance & Pearson Correlation & 1 & .000 \\
& Sig. (2-tailed) & & .796 \\
Awareness & $\mathrm{N}$ & 24 & 24 \\
& Pearson Correlation & .000 & 1 \\
& Sig. (2-tailed) & .796 & 24 \\
\hline
\end{tabular}

\subsection{Causes of Non-Compliance with the Quality Standards}

The research identified four factors that may have led to non compliance with the quality assurance standards. These factors include lack of awareness of the standards, internal auditors not being members of IIA, internal auditors not adopting the IPPF and the age of internal audit department. The respondents were requested to give the extent to which they agree that each of the four may lead to non compliance.

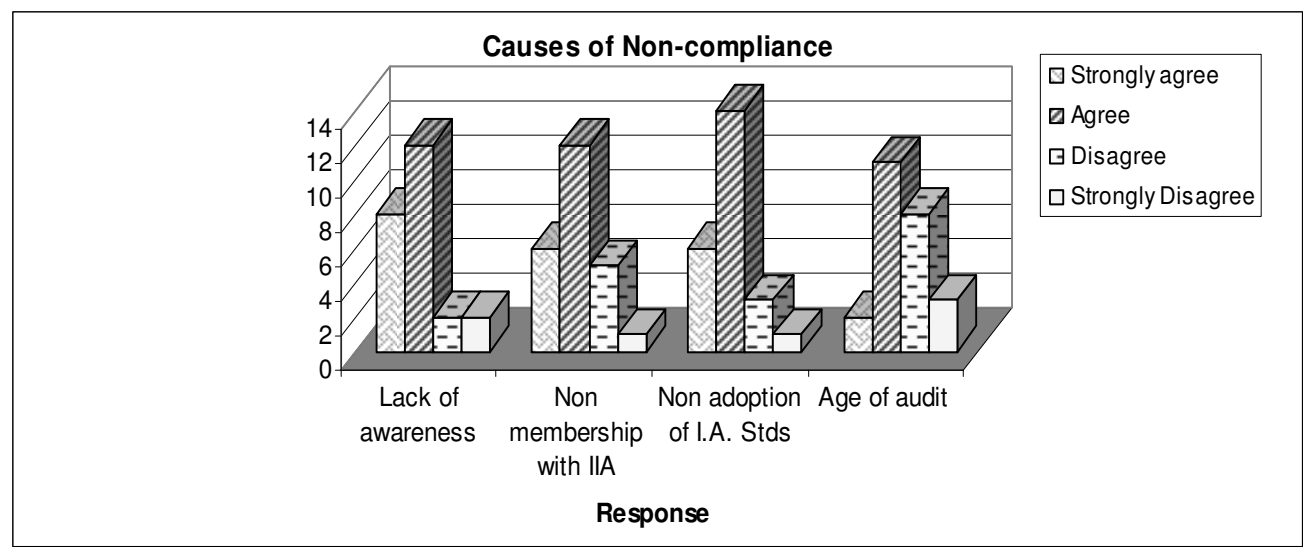

Figure 8. Causes of non-compliance

The respondents confirmed to the research that internal auditor's awareness of standards, membership with IIA, and adoption of internal auditing standards positively affects compliance with quality assurance standards. The factor that the respondents did not fully confirm was the age of internal audit department. The respondents were asked question on the other factors that could contribute to lack of compliance with the quality assurance standards. They identified the factors such as; lack of commitment by the members of staff, qualifications of the CAE and/or the staff, lack of training such as seminars, lack of awareness by the IIA, the government's secrets act may also hinder especially external assessment, high cost of carrying out quality assessment, the time involved in conducting quality assessment, and biases in conducting the quality assessments.

Poor governance and corruption in corporations could also be factors that contribute to lack of compliance with quality assurance standards by the internal auditors. These factors may not have been mentioned by the respondents since this study was carried out based on self assessment. This research did not dwell on these factors since they were outside the scope of this research.

\subsection{Benefits of High Quality Audit Work}

Internal auditors work mainly involves providing assurance and consultancy services to the management as 
to whether the internal control system, risk frameworks and governance processes put in place by the management are working as intended. This implies that the quality audit work may go a long way in enhancing efficiency in the organization.

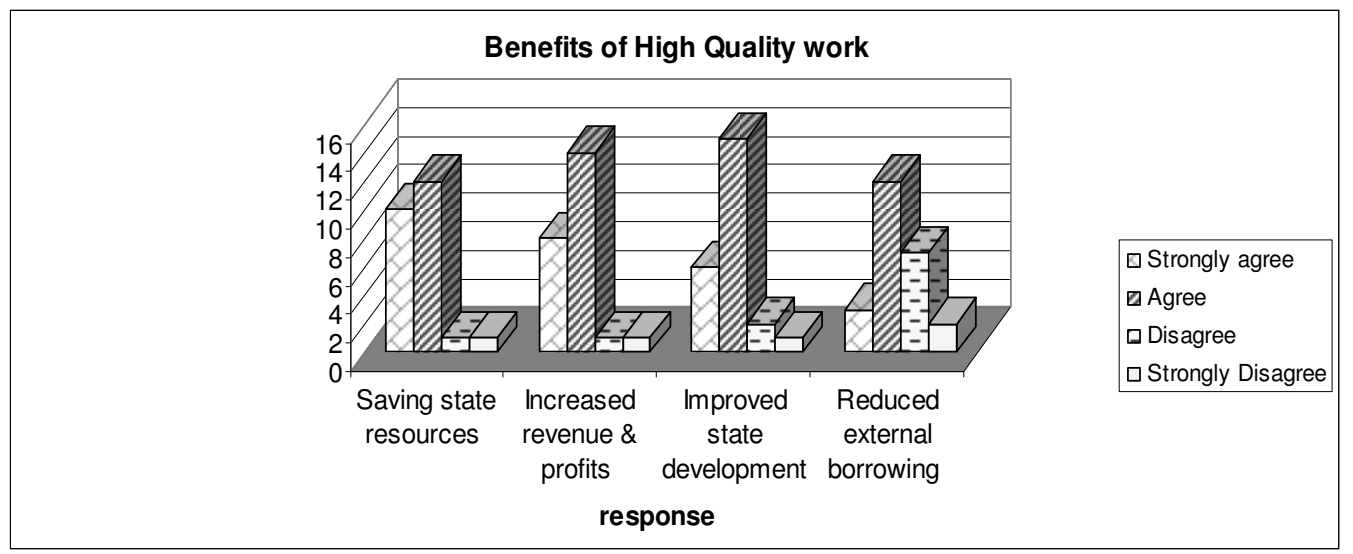

Figure 9. Benefits of high quality work

The research identified four possible benefits that could accrue to the state owned corporations and to the state as a result of quality internal audit work by the auditors in such organizations. Most of the respondents agreed or strongly agreed that the four possible benefits of high quality internal audit work are true. However more respondents disagreed or strongly disagreed with the point reduced external borrowing as compared with the other three points as indicated by the comparative bar graph.

\subsection{Frequency of Reporting Quality Assurance Results}

The respondents also provided a response on the frequency of reporting the results of quality assurance to the board or the audit committee.

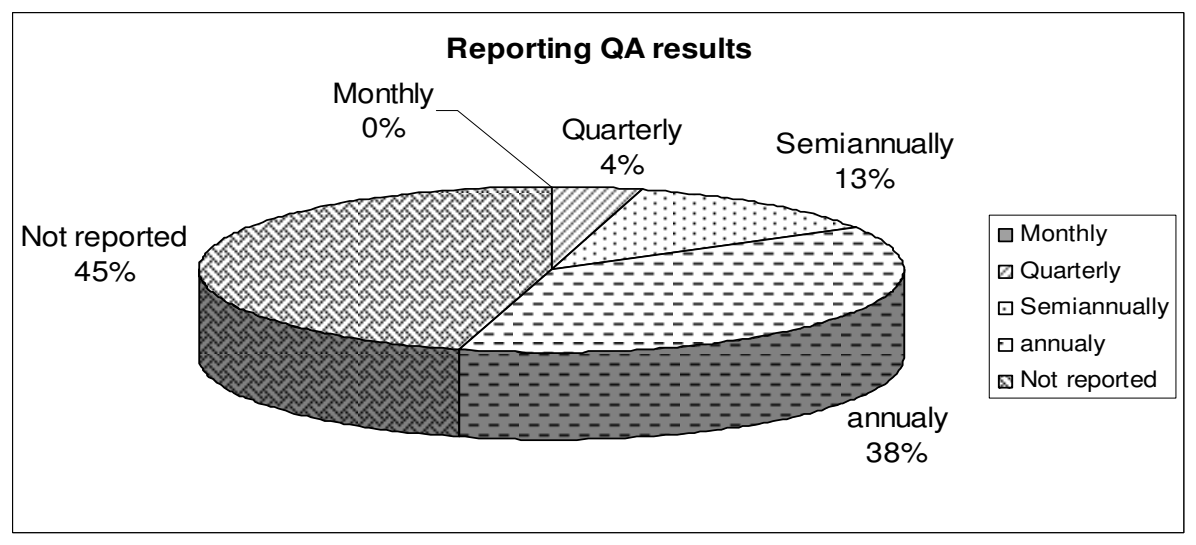

Figure 10. Frequency of reporting quality assurance results

The results imply that almost half of the respondents did not report the results of their quality assessment to a higher authority. This could lead to a conclusion that the quality assessments exercise carried out by some internal audit units does not satisfy the intended objective. The internal audit units could be carrying out the quality assessments for the sake of compliance with the standards which should not be the case.

\subsection{Hypothesis Testing}

The hypothesis in this study was internal auditors in state owned corporation do not comply with quality assurance standards: 
Okibo, B. W. \& Kamau, C. G.

H0 - Internal auditors in State Owned Corporations do not comply with the Quality Assurance Standards (Compliance, $\mu=0$ )

H1 - Internal auditors in State Owned Corporations comply with the Quality Assurance Standards (Compliance, $\mu>0$ )

\subsection{Level of Significance}

The test was carried out at $95 \%$ confidence interval therefore type I error $(\propto)$ was $5 \% .(\propto=0.05)$.

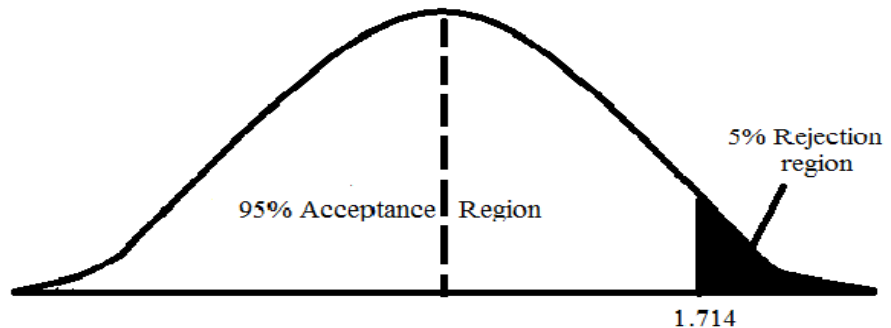

Figure 11. Test statistic and decision rule

Degrees of freedom $=n-1=24-1=23$

Critical $\mathrm{t}$ from the students $(\mathrm{t})$ distribution table $=1.714$

Decision rule - reject the null hypothesis (H0) if calculated $t$ falls within the rejection region i.e. the calculated $\mathrm{t}>1.714$

\subsection{Calculation}

Data on the compliance with quality asurance standards taking into account the data on internal quality assesment, external quality assesment and reporting of quality assurance results was used in testing the hypothesis. Descriptive statistics were calculated using SPSS program.

\section{Table 7}

Descriptive Statistics

\begin{tabular}{lccccc}
\hline \multicolumn{1}{c}{ Items } & $N$ & Minimum & Maximum & $M$ & $S D$ \\
\hline Compliance & 24 & 0.00 & 3.00 & 0.672 & 1.767 \\
Valid N (listwise) & 24 & & & & \\
\hline
\end{tabular}

$$
\mathrm{t}=\frac{\mathrm{X}-\mu}{\sigma / \sqrt{\mathrm{n}}}=\frac{0.672-0}{1.767 \div \sqrt{ } 24}=1.863
$$

Confidence interval at $95 \%$ level

Confidence Interval $=$ Point estimate \pm Test statistic $\mathrm{X}$ Standard Error

Confidence Interval $=\mathrm{X} \pm 1.714(\sigma / \sqrt{ } \mathrm{n})$

Confidence Interval $=0.672 \pm 1.714(1.767 / \sqrt{ } 24)=0.672 \pm 0.618$

Range of confidence interval is 0.052 to 1.290

The researchers were therefore $95 \%$ confident that the true mean of the population lies between 0.052 and 1.290 


\subsection{Conclusion}

Since calculated t score (1.863) is greater than the critical $t$ score (1.714), the research rejected the null hypothesis. Therefore the hypothesis testing statistics leads us to the conclusion that the internal auditors in State Owned Corporations comply with the Quality Assurance Standards. However the calculated t score was very close to the tail but in the rejection region indicating that the level of compliance was very low. The confidence interval statistics gave a range of true mean of population as ranging from 0.052 to 1.290 . If the true mean takes up the lower limit for example, the compliance level is close to zero. The research therefore could not reject the null hypothesis after considering the confidence intervals. The final conclusion of the research was that the internal auditors in state owned corporations did not comply with quality assurance standards.

\section{Summary, Discussion and Conclusion}

In order for the internal auditors to do their work professionally, the IIA developed standards for them. In the earlier sections of this project it was stated that internal auditors seemed not to comply with the quality assurance standards. Non compliance with quality assurance standards has a number of negative consequences including wastage of resources. The research identified a number of factors that could lead to non compliance with quality assurance standards which included; lack of awareness of standards, non-membership with IIA, non adoption of the internal auditing standards, and the age of internal audit. Understanding of the quality assurance standards was also included as a factor affecting the level of compliance with the quality assurance standards.

\subsection{Discussion}

The research observed that there were a few corporations who reported that they comply with quality assurance standards yet they do not carry out both internal and external quality assessments. A few other corporations reported that they carried out either internal quality assessment or external quality assessment or both yet their results are not communicated to the board or the audit committee. The research identified five factors that would contribute to lack of compliance with quality assurance standards. They include; lack of awareness of standards which most respondents agreed that it's a major factor; non-membership with IIA, most of the respondents agreed with it; non adoption of IPPF, which most the respondents also agreed with; age of the internal audit department, which slightly more than half of the respondents agreed with while the rest disagreed with it. The fifth factor was, understanding of the quality assurance standards. The data supported that the higher the understanding of quality assurance standards, the higher the likelihood of complying with the standards.

The respondents also identified quite a number of other factors that would contribute to lack of compliance with the quality assurance standards. In summary the factors includes; lack of commitment by the members of staff, qualifications of the CAE and/or the staff, lack of training such as seminars, lack of awareness by the IIA, the secrets act may also hinder especially external assessment, high cost of carrying out quality assessment, the time involved in conducting quality assessment, and biases in conducting the quality assessments.

The respondents also indicated that training on the need for quality assurance, morale boosting to the staff, to improve awareness among decision and policy makers, awareness by the IIA, budgeting and planning for the quality assessment can help improve compliance. The research also identified the benefit of compliance with quality assurance standards as high quality audit work. The benefits of high quality internal audit work include; saving of state resources, increased revenue and profits for the state corporations, improved state development and reduced external borrowing.

\subsection{Conclusion}

The research rejected the null hypothesis after considering the internal validity of the data collected and 
carrying out the t-test hypothesis testing. The conclusion therefore was that the internal auditors in state owned corporations comply with the quality assurance standards. However there was generally low compliance with the quality assurance standards considering the performance of internal and external quality assessments and reporting of the quality assessment results. There is need for improvement in compliance with quality assurance standards since the level of compliance as indicated by the results of this research is wanting.

\section{References:}

Abdolmohammadi, M. J. (2009). Factors associated with the use of and compliance with the IIA standards. International Journal of Auditing, 13(1), 27-42. <http://dx.doi.org/10.1111/j.1099-1123.2008.00393.x >

Adamec, B. A., Linda, M., Leinicke, A., Joyce, O. W., \& Rexroad, M. (2005). Getting a leg up. Internal Auditor, June, 7-9.

Anderson, D. R. (2007). Statistics for business and economics. London, UK: Thomson Learning.

Astrup, K. (2008). Spotlight on the strategic plan. International Journal of Government Auditing, 35(4), 21.

Black, K. (2010). Business statistics: Contemporary decision making. Jefferson City: John Willey \& Sons.

Boon, K., McKinnon, J., \& Ross, P. (2008). Audit services quality in compulsory audit tendering: Preparer perceptions and satisfaction. Accounting Research Journal, 21(2), 93-122. <http://dx.doi.org/10.1108/10309610810905917>

Brewerton, P., \& Millward, L. (2001). Organizational research methods: A guide for students and researchers. London, UK: Sage Publications Ltd.

Bryan, B. J. (1996). Factors influencing compliance with GAAS reporting standards on private sector engagements. Managerial Auditing Journal, 11(6), 54-58. $<$ http://dx.doi.org/10.1108/02686909610125159>

Burdick, S. L. (2003). Design research: Methods and perspectives. Los Angeles, CA: Library of Congress.

Colbert, J. L. (2002). New and expanded internal audit standards. CPA Journal, May. Retrieved from http://findarticles.com/p/articles/mi_qa5346/is_200205/ai_n21313720/?tag=content;col1

Cooper, D. R., \& Emory, C. W. (1995). Business research methods. New York, NY: McGraw Companies Inc.

Cox, G. (2007). Going up. Internal Auditor, August. Retrieved June 3, 2010 from http://www.theiia.org/intAuditor/feature-articles/2007/august/going-up/

Crowther, D., \& Lancaster, G. (2008). Research methods: A concise introduction to research in management and business consultancy (2nd ed.). Jordan Hill, Oxford: Elsevier Ltd.

Dattalo, P. (2008). Determining the sample size: Balancing power, precision, and practicality. New York, NY: Oxford University Press.

Edwards, J., \& Wolfe, S. (2005). Compliance: A review. Journal of Financial Regulation and Compliance, 13(1), 48-59. <http://dx.doi.org/10.1108/13581980510622018>

Engel, R. J., \& Schutt, R. K. (2010). Fundamentals of social work research. CA: Sage Publications Inc.

Fakhfakh, M., \& Consuelo, M. (2007). Measurement of compliance with ISA 700: The case of audit reports published by international accounting firms in Tunisia. Journal of Human Resources Costing and Accounting, 11(1), 4-29. <http://dx.doi.org/10.1108/14013380710746384>

Free Online Dictionary. (2010). Retrieved June 22, 2010 from http://www.thefreedictionary.com/awareness

Gavin, T. A., Roy, R. A., \& Sumners, G. E. (1990). A corporate code of conduct: The internal auditor's role. Leadership \& Organization Development Journal, 11(3), 32-40. <http://dx.doi.org/10.1108/EUM0000000001152>

Gendron, Y. (2010). Getting Inside the black box: A field study of practices in effective audit committees. Auditing: A Journal of Practice and Theory. Retrieved December 6, 2010 from http://findarticles.com/p/articles/mi_go2486/is_200403/ai_n6424321/

Government of Kenya. (2007). Kenya vision 2030: The popular version. Nairobi, Kenya: Government Printer. Gravetter, F. (2009). Research methods for behavioral sciences $\left(3^{\text {rd }}\right.$ ed.). Wadsworth Cengage Learning.

Hernandez, H. (2010). Quality audit as a driver for compliance to ISO 9001:2008 standards. The TQM Journal. 22(4), 454-466. <http://dx.doi.org/10.1108/17542731011053361> 
Internal auditors' compliance with Quality Assurance Standards: A case of state owned corporation

Johnson, S., Walker, J., \& Jameson, R. S. (1828). A dictionary of the English language. London, UK: George Cowie \& Co.

Kerlinger, F. N. (1970). Foundations of behavioral research. New York, NY: Holt, Rinehart and Winston.

Khalifa, R., Sharma, N., Humphrey, C., \& Robson, K. (2007). Discourse and audit change: Transformations in methodology in the professional audit field. Accounting, Auditing and Accountability Journal, 20(6), 825-854. <http://dx.doi.org/10.1108/09513570710830263>

Kihara, G. (2009). Parastatal heads meet at coast over governance. Daily nation, November, p. 24. Nairobi, Kenya: Nation Centre.

Kolin, P. C. (2010). Successful writing at work (9th ed.). Boston, MA: Wadsworth Cengage Learning.

Koross, K. (2009). Five sent home as probe starts on Sh 30 million loss. Daily Nation, October, p. 9. Nairobi, Kenya: Nation Centre.

Leedy, R. D. (1989). Practical research: Planning and design (4th ed.). London, UK: Collier Macmillan.

Lin, Z. J., Liu, M., \& Wang, Z. M. (2009). Market implication of the audit quality and auditor switches: Evidence from China. Journal of International Financial Management and Accounting, 20(1), 35-78. <http://dx.doi.org/10.1111/j.1467-646X.2009.01026.x>

Madani, H. H. (2009). The role of internal auditors in ERP-based organizations. Journal of Accounting and Organizational Change, 5(4), 514-526. <http://dx.doi.org/10.1108/18325910910994702>

Maxwell, J. (2005). A qualitative research design: An interactive approach. CA: Sage Publications Inc.

Mihret, D. G., \& Woldeyohannis, G. Z. (2008). Value added role of internal audit: An Ethiopian case study. Managerial Auditing Journal, 23(6), 567-595. <http://dx.doi.org/10.1108/02686900810882110>

Moeller, R. (2009). Brink's modern internal auditing: A common body of knowledge. New Jersey: John Wesley $\&$ Sons Inc.

Mugenda, A. G. (2008). Social science research: Theories and principles. Nairobi, Kenya: Applied Research \& Training Services.

Nachmias, D. (1996). Research methods in the social sciences (5th ed.). London, UK: St. Martin's Press Inc.

Nordin, C. (2005). Internal auditing in the public sector: a consultative forum in Nairobi, Kenya, shores up best practices for government audit professionals in developing nations. Internal Auditor, August. Retrieved May 31, 2010 from http://findarticles.com/p/articles/mi_m4153/is_4_62/ai_n15890726/

Omar, N. H., Alwi, M. J., \& Alwi, Z. A. (2003). Quality monitoring of the accounting profession: Are we ready for peer review? Journal of Financial Reporting and Accounting, 1(1), 49-66.

<http://dx.doi.org/10.1108/19852510380000667>

Owour, A. (2010). Welcome aboard. Retrieved June 3, 2010 from http://www.theiia.org/chapters/index.cfm/view.message/cid/314

Pickett, K. H. S. (2004). The internal auditor at work: A practical guide to everyday challenges. New Jersey: John Wiley \& Sons Inc.

Rasli, A. (2006). Data analysis and interpretation: A handbook for post graduate social sciences. Selangor Darul Ehsan, Malaysia: Percetakan Info Meditasi.

Saleemi, N. A. (2008). Quantitative techniques simplified. Nairobi, Kenya: Saleemi Publications Limited.

Saturday Nation Correspondent. (2010). Six charged with defrauding NSSF of Sh1.6bn out on bail. Daily Nation, April, p. 9. Nairobi, Kenya: Nation Centre.

Schneider, A. (2009). Does expectation of finding deficiencies impact internal audit work? Journal of Applied Accounting Research, 10(2), 122-131. <http://dx.doi.org/10.1108/09675420910984682>

Shenoy, G. V., \& Srivastave, U. K. (2002). Business statistics. New Delhi, India: New Age International Limited.

Shih, K. H., Hsieh, Y. R., \& Lin, B. S. (2009). Moderator effects to internal audits' self-efficacy and job involvement. International Journal of Accounting \& Information Management, 17(2), 151-165.

Spraakman,G. (2001). Internal audit at the historical Hudson's bay company: A challenge to accepted history. The Accounting Historians Journal, June. Retrieved June 12, 2010 from http://findarticles.com/p/articles/mi_qa3657/is_200106/ai_n8962777/pg_4/?tag=content;col1

Stephens, L. J. (2006). Beginning statistics (2 $2^{\text {nd }}$ ed.). New York, NY: McGraw Companies Inc. 
Okibo, B. W. \& Kamau, C. G.

The IIA. (2010). IIA History and milestones. Retrieved June 12, 2010 from http://www.theiia.org/theiia/about-the-institute/history-milestones/

The IIA. (2010). Membership types. Retrieved June 8, 2010 from http://www.theiia.org/membership/join-now/

The IIA. (2010). Membership. Retrieved June 8, 2010 from http://www.theiia.org/membership/?search=membership

The IIA. (2010). The IIA works towards global recognition of internal auditing. Retrieved June 2, 2010 from http://www.theiia.org/iiatoday/features/focus-on=professionalism

The Institute of Internal Auditors (IIA). (2010). Retrieved June 3, 2010 from http://www.theiia.org/theiia/?search=history\%20of\%20IIA

The Institute of Internal Auditors Research Foundation. (2006). A global summary of common body of Knowledge. Florida: Altamonte Springs.

The Institute of Internal Auditors Research Foundation. (2007). IIA standard 1312-external quality assessments: Results, tools, techniques and lessons learned. Florida: Altamonte Springs.

The Institute of Internal Auditors. (2004). The professional practices framework. Florida: Altamonte Springs.

Walliman, N. (2005). Your research project ( $2^{\text {nd }}$ ed). London, UK: Sage Publications.

Zandstra, H. G., Price, E. C., Litsinger, J. A., \& Morris, R. A. (1981). A methodology for on farm cropping systems research. Manila: The International Rice Research Institute. 